ОРТОПЕДИЧНА СТОМАТОЛОГІЯ

УДК $616.314-051.9-087$

DOI

\author{
(СЮ. Л. Бандрівський, О. О. Бандрівська
}

ДВН3 «Тернопільський державний медичний університет імені І. Я. Горбачевського»

\title{
Рівень психологічного комфорту в пацієнтів із генералізованим пародонтитом і різною груповою приналежністю крові
}

\begin{abstract}
Резюме. У статті представлено й оцінено за допомогою індексу ОНІР-14 рівень психологічного комфорту у хворих на генералізований пародонтит і в людей без захворювань його тканин. Доведено, що «якість життя», за даними тестування, пацієнтів із генералізованим пародонтитом значно нижче, ніж у здорових осіб. При цьому в носіїв О (I) групи крові обох груп дослідження рівень психологічного комфорту був нижчим і розцінювався як «поганий» у хворих на генералізований пародонтит i «незадовільний» у людей без уражень зубоутримувальних тканин.
\end{abstract}

Ключові слова: генералізований пародонтит, психологічний комфорт.

Ю. Л. Бандривский, О. О. Бандривская

ГВУЗ «Тернопольский государственный медицинский университет имени И. Я. Горбачевского»

\section{Уровень психологического комфорта в пациентов с генерализованным пародонтитом и различной групповой принадлежностью крови}

\begin{abstract}
Резюме. В статье представлен и оценен с помощью индекса OHIP-14 уровень психологического комфорта у больных генерализованным пародонтитом и в людей без заболеваний его тканей. Доказано, что «качество жизни», по данным тестирования, у больных генерализованным пародонтитом значительно ниже, чем у здоровых лиц. При этом у носителей O (I) группы крови обеих групп исследования уровень психологического комфорта был ниже и расценивался как «плохой» у больных генерализованным пародонтитом и «неудовлетворительный» у людей без поражений тканей пародонта.
\end{abstract}

Ключевые слова: генерализованный пародонтит, психологический комфорт.

\section{Yu. L. Bandrivskyi, O. O. Bandrivska}

I. Horbachevsky Ternopil State Medical University

\section{Comfort level of psychological in patients with different generalized periodontitis group affiliation blood}

Summary. The article presented and evaluated by an index OHIP - 14, the level of psychological comfort in patients with generalized periodontitis in people without periodontal tissue diseases. It is proved that the "quality of life», according to testing in patients with generalized periodontitis is significantly lower than in healthy individuals. Thus, the carriers O (I) blood groups of both studies psychological comfort level was lower and is seen as «bad» in patients with generalized periodontitis and «poor» people without lesions periodontal tissues.

Key words: generalized periodontitis, psychological comfort.

Вступ. Захворювання пародонта у зв’язку з високою поширеністю, схильністю до прогресування призводять до втрати основних функцій його і зубощелепної системи. У загальному становлять важливу медико-соціальну проблему і суттєво впливають на якість життя людей [ 1-4].

Уявлення про «якість життя» давно цікавить соціологів та лікарів і має дві сторони зовнішню, зумовлену ступеневим розвитком 
суспільства, держави та внутрішню, залежну від самої «природи» людини [ 4, 6]. Проведення подібних досліджень за визначенням «якості життя» - високоінформативний і ефективний метод оцінки стану здоров'я як населення у цілому, так і окремих соціальних груп. Багато зарубіжних дослідників розпрацювали й описали багато методик визначення психологічного комфорту пацієнтів [1-3, 5, 6]. У заключенні клінічного стоматологічного дослідження у пацієнтів груп спостереження ми проводили психологічне тестування - вивчення якості життя (ЯЖ) за даними анкетування ОНІР-14. Профіль впливу стоматологічного здоров'я ( Oral Health Impact Profile) [5, 7].

У спеціалізованому анкетуванні (ЯЖ) ОНІР 14 виділено наступні підпункти, які відповідають етапам розвитку ускладнень хвороби за D. Locker [6, 7]: функціональні обмеження, фізичний біль, психологічний дискомфорт, фізична та соціальна дієздатність, зниження успішності у житті. Підпункти і питання ОНІР - 14 узгоджені між собою, а анкетування містить негативне формування питань, що дозволяє визначити вплив здоров'я порожнини рота на якість життя пацієнтів [7].

Метою дослідження було оцінити стан психологічного комфорту у хворих на генералізований пародонтит із різною груповою приналежністю крові за допомогою тесту ОНІР-14.

Матеріали і методи. Повне клінічне стоматологічне обстеження провели у 269 хворих на генералізований пародонтит (основна група) та 190 осіб без уражень зубоутримувальних тканин (порівняльна група). Діагноз захворювань тканин пародонта встановлювали за класифікацією М. Ф. Данилевського (1994) 3 доповненнями Г. Ф. Білоклицької (2010) та уточнювали за допомогою параклінічних індексів [3]. При завершенні пародонтологічного дослідження проводили психологічне тестування за даними анкетування OHIP-14. Кожне питання тесту було оцінено у певну кількість балів залежно від тяжкості доторкання у ньому проблеми. П’ятибальна система відповідей на 14 питань («ніколи», «майже ніколи», «рідко», «зазвичай», "дуже часто») інтерпретувалася наступним чином: шкала оцінки відповідала «добрій» якості життя при кількості балів за анкетою 0-14, «задовільному» - 15-28 балів, «незадовільному» 29-42 бали, «поганому» - 43-56 балів [5, 7]. Отримані результати були опрацьовані статистично.

Результати досліджень та іх обговорення. У результаті проведеного анкетування ми встановили, що хворі на ГП I-III ступенів тяжкості оцінювали «якість життя» за тестом OHIP-14 як «незадовільний» при значенні індексу 39,87 $22,99, \mathrm{p}<0,01$. При цьому в носіїв О (I) та А (II) груп крові, хворих на ГП, дані індексу були максимальні $(49,14 \pm 5,97$ та $44,23 \pm 5,85$, $\left.\mathrm{p}_{1}>0,05\right)$ та засвідчували «поганий» рівень психологічного комфорту. Максимальні дані $\left((32,32 \pm 5,63)\right.$ бала, $\left.\mathrm{p}_{1}<0,05\right)$, які характеризували «незадовільний» рівень психологічного комфорту, були у представників В(III) групи крові хворих на генералізований пародонтит. У пацієнтів порівняльної групи, в яких не об'єктивізувались захворювання тканин пародонта, за даними тестування, психологічний комфорт розцінювали у середній, як «добрий» 3 індексною оцінкою 5,39ะ1,64. Однак максимальні значення тесту OHIP-14 були виявлені в опитуваних 3 О (I) групою крові $(7,35 \pm 2,45)$ при мінімальних даних тесту $(3,83 \pm 1,27)$ у осіб з $\mathrm{AB}(\mathrm{IV})$ групою крові, $\mathrm{p}_{1}>0,05$.

Суттєвий вплив при відповідях на питання за запропонованим тестом мали незадовільне харчування, незручності під час споживання їжі, розмові, а також дискомфорт під час спілкування з людьми, у тому числі на роботі, пов’язаний з відсутністю зубів. У середньому в результаті дослідження виявлено найбільш важливі питання, які вплинули на результати тестування (рис.):

- Чи спостерігаєте Ви утруднення при вимові слів із-за проблеми з зубами, слизової оболонки порожнини рота або протезів?

У хворих на ГП середній бал на дані запитання складав $(3,66 \pm 0,61)$ бала проти $(1,11 \pm 0,37)$ бала в осіб без уражень тканин пародонта, $\mathrm{p}<0,01$.

- Чи відмічаєте Ви больові відчуття у ротовій порожнині у зв'язку із-за проблеми з зубами, слизової оболонки порожнини рота або протезів?

У пацієнтів основної групи середній бал на це запитання був значно вище, ніж у осіб групи порівняння $((4,25 \pm 1,22)$ бала проти $(0,74 \pm 0,24)$ бала, $p<0,05)$.

- Чи відмічаєте Ви незручності у зв'язку із-за проблеми з зубами, слизової оболонки порожнини рота або протезів?

На це запитання хворі на ГП переважно давали відповіді «зазвичай» та "дуже часто» при середньобальній оцінці $(4,08 \pm 1,21)$ бала, $\mathrm{p}<0,05$. Проте опитувані без захворювань тканин пародонта на дане запитання переважно відповідали «майже ніколи» та "рідко», а середньобальна оцінка у них дорівнювала $(0,63 \pm 0,21)$ бала. 


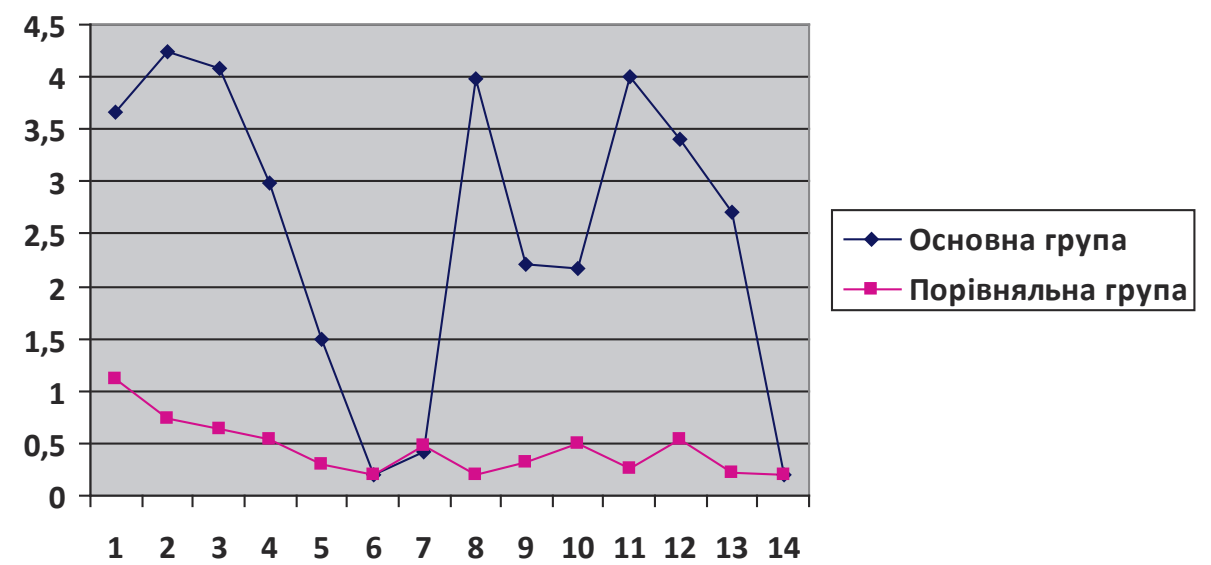

Puc. Графічне зображення психологічного комфорту в пацієнтів груп дослідження.

- Чи виникають у Вас утруднення при споживанні їжі із-за проблеми з зубами, слизової оболонки порожнини рота або протезів?

Середній бал на це питання у хворих на ГП склав $(3,99 \pm 1,19)$ бала проти $(0,26 \pm 0,08)$ бала в осіб порівняльної групи, $\mathrm{p}<0,01$.

- Чи відчуваєте Ви себе ніяково при спілкуванні з людьми у зв'язку з проблемами із зубами, слизовою оболонкою порожнини рота або протезами?

У хворих на ГП середньобальна оцінка на це питання складала $(4,01 \pm 1,19)$ бала в осіб групи порівняння, $\mathrm{p}<0,01$.

Слід зазначити, що у носіїв O (I) групи крові обох груп дослідження середньобальна оцінка за наведеними вище запитанням була найвищою: $(4,66 \pm 1,24)$ бала в основній та $(0,94 \pm 0,31)$ бала у порівняльній групах, $\mathrm{p}<0,01$.

Мінімальну середньобальну оцінку за цими питаннями визначали у носіїв В (III) групи хворих на ГП $(3,31 \pm 1,10)$ бала та в осіб без захворювань тканин пародонта з AB(IV) групою $(0,48 \pm 0,16)$ бала.

\section{Список літератури}

1. Веденеева Е. В. Роль стоматологического лечения в улучшении качества жизни пациентов / Е. В. Веденеева : автореф. дисс. на соскание уч. степени канд. мед. наук. - М., 2010. - 24 с.

2. Грачев Д. И. Повышение эффективности ортопедического лечения и качества жизни больных с полным отсутствием зубов на нижней челюсти / Д. И. Грачев // Стоматолог. - 2011. - № 3 - С. 15-17.

3. Заболотний Т. Д. Запальні захворювання пародонту / Т. Д. Заболотний, А. В. Борисенко, Т. І. Пупін. Львів : ГалДент, 2013. - 205 с.

4. Смирнягина В. В. Возможность использования критерия качества жизни для оценки эффектив-
Привертало увагу те, що опитувані обох груп на запитання «Чи доводиться Вам повністю випадати з життя із-за проблеми із зубами, слизової оболонки порожнини рота або протезів?», «Чи виникають у Вас затруднення у звичайній роботі із-за проблеми з зубами, слизової оболонки порожнини рота або протезів?» та пацієнтів без захворювань тканин пародонта - «Чи виникає у Вас утрудненне споживання їжі із-за проблеми з зубами, слизової оболонки порожнини рота або протезів?» давали відповідь «Майже ніколи».

Висновки. У хворих на генералізований пародонтит у результаті анкетування визначено низький рівень психологічного комфорту порівняно з особами без уражень тканин пародонта. Максимальні індексні дані визначались у носіїв 0 (I) групи обох груп дослідження, що може бути використано при плануванні диференційованих комплексних лікувальнопрофілактичних заходів, скерованих на попередження виникнення, ранню реабілітацію запальних захворювань тканин пародонта.

ности лечения хронического генерализированного пародонтита средней степени / В. В. Смирнягина : автореф. дисс. на здобуття наук. ступеня канд. мед. наук. - М., 2007. - 25 c.

5. Birch S. Measuring dental health: improvements on the DMF index / Birch S. // Ommynity Dental Health. 1996. - Vol. 3. - P. 303-311.

6. Naito M. Oral health status and health - rebated quality of life: a systematic review/ M. Naito // Gornal of Oral Science. 2006. - Vol. 1. - P. 1-7.

7. Sheiham A. Oral health, general health and quality of life / A. Sheiham // Bulletin of the World Health Organization. - 2005. - Vol. 9. - P. 644-646. 